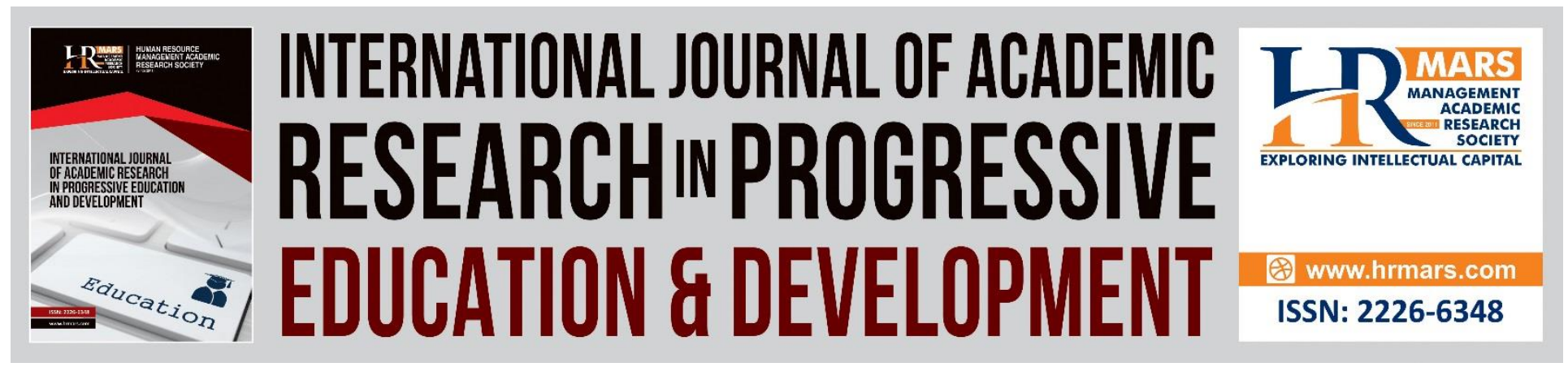

\title{
Technical Capability, Instructional Strategies and Learners' Engagement in Online Learning Instruction: Basis for Framework Development
}

\author{
Marifel O. Sison, Susana Cabria Bautista
}

To Link this Article: http://dx.doi.org/10.6007/IJARPED/v10-i2/9799

DOI:10.6007/IJARPED/v10-i2/9799

Received: 12 February 2021, Revised: 10 March 2021, Accepted: 27 March 2021

Published Online: 24 April 2021

In-Text Citation: (Sison \& Bautista, 2021)

To Cite this Article: Sison, M. O., \& Bautista, S. C. (2021). Technical Capability, Instructional Strategies and Learners' Engagement in Online Learning Instruction: Basis for Framework Development. International Journal of Academic Research in Progressive Education and Development, 10(2), 261-287.

Copyright: (C) 2021 The Author(s)

Published by Human Resource Management Academic Research Society (www.hrmars.com)

This article is published under the Creative Commons Attribution (CC BY 4.0) license. Anyone may reproduce, distribute, translate and create derivative works of this article (for both commercial and non-commercial purposes), subject to full attribution to the original publication and authors. The full terms of this license may be seen at: http://creativecommons.org/licences/by/4.0/legalcode

Vol. 10 (2) 2021, Pg. 261 - 287 


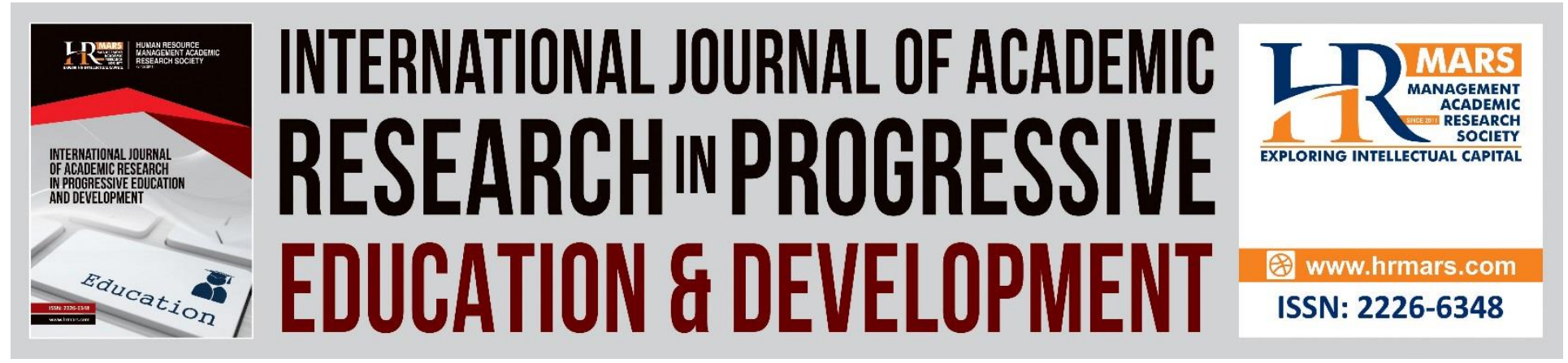

\title{
Technical Capability, Instructional Strategies and Learners' Engagement in Online Learning Instruction: Basis for Framework Development
}

\author{
Marifel O. Sison, Susana Cabria Bautista, LPT EdD FRIEdr \\ University of Perpetual Help System Laguna \\ Email: sison.marifel@uphsl.edu.ph, bautista.susana@uphsl.edu.ph
}

\begin{abstract}
Schools are faced with the challenge of developing and implementing an online framework model especially in Radiology technology program. Online courses offer an excellent way for students to broaden their educational opportunities and stay competitive in the everdemanding realm of education. Learning engagement in technology mediated learning and its effect on learning effectiveness and satisfaction, and their experimental data showed that the effects of technology-mediated learning were mediated by learning engagement, learning engagement had a positive effect on learning effectiveness whether in face-to-face learning or technology-mediated learning. Moreover, effective design of instructional materials elicits appropriate cognitive processes in the learner and mediates more successful learning outcomes ensuring an engaging and worthwhile online learning is necessary to achieve the same result of achieving quality learning, therefore it is important to address these topics on faculty technical capability, standard instructional strategies and learner's engagement strategies to the development of dynamic and an effective online framework model for Radiology technology program. This study aimed to assess the teachers' level of technical capability, instructional strategies utilization and level of learners' engagement strategies that set as the basis to enhance the online framework model for radiology technology program. Descriptive correlational research design was employed. The study revealed that Radiologic Technology Professors in terms of technical capabilities, instructional strategies and learner's engagement had a very confident concept in online learning. In essence, the results yield the delivery of education with the use of technology introduces a platform that gives a more accessible learning system.

Keywords: Technical Capability, Instructional Strategies, Learners' Engagement, Online Learning Instruction
\end{abstract}




\section{Introduction}

Delivering education with the use of technology introduces a platform that gives a more accessible learning system. Therefore, the government promotes the use of Information and Communication Technologies in all sectors. As stated in Republic Act No. 10844. This provision rationalizes the effort of the Commission of Higher Education (CHED) to deliver a quality and accessible education especially in times of crisis. As stated in CHED Memorandum No. 4, Series of 2020 that it has become an urgent need to explore other innovative learning modalities that will facilitate migration from traditional to flexible teaching and learning options. It is also stipulated in the said memorandum that Higher Education Institutions (HEIs) are encouraged to maximize the use of technology to support learning and teaching. The Commission on Higher Education calls it "flexible learning" which also includes online or e-learning that many colleges and universities in the Philippines have been doing even in the past (Mansilla, 2020).

Furthermore, knowledge and skills developed for teaching face-to-face classes are not adequate preparation for teaching online (Yang, 2018). Other issue in an online learning raised by Baran et.al in Kebritchi, et.al (2017) is that instructors of online education preparation programs may not know how to prepare instruction for transition from the traditional face-toface training to the online teaching. Kebritchi, et.al (2017) pointed out also that content issues included the role of instructors in content development, integration of multimedia in content, role of instructional strategies in content development, and considerations for content development. Although, according to McMurtry (2016) the instructor's teaching approach is student-centered, focusing not just on providing the content and grading the student's efforts, but also on whether each student is engaged in the learning process, understanding the content, and making progress toward the course goals. It indicates that instruction should encourage independent learning that is incorporated with interactive technological instructional strategies.

Online courses offer an excellent way for students to broaden their educational opportunities and stay competitive in the ever-demanding realm of education. Ensuring an engaging and worthwhile online learning is necessary to achieve the same result of achieving quality learning. Hence, students embarking on the path of higher education through online coursework need to be self-motivated, independent, and responsible learners (Gilbert, 2018). But pushing oneself to engage in an online educational setting is just one factor that needs a motivator. Findings suggest that interactivity seems to be a key in keeping students involved and achieving, with specific activities routinely favored by students. Farrel et.al (2020) postulated that a successful online student engagement was influenced by a number of psychosocial factors such as peer community, an engaging online teacher, and confidence and by structural factors such as life load and course design. However, in the study of Hu et.al (2018) it found out that due to lack of communication between teachers and students, the performance of students who participate in online learning is not satisfactory, and their persistence and efficiency are also poor.

With such, this study aimed to determine the technical capability, instructional strategies and learners' engagement in online learning instruction. This will also serve as the basis for a proposed online learning instruction framework for Radiologic Technology students. 


\section{Methods}

The study used descriptive-correlational research design since it determined the technical capability, instructional strategies and learners' engagement in online learning instruction in different Higher Educational Institution in Region 4A. Likewise, it identified possible patterns of relationships that exist among variables. Data used in the investigation came from 58 Radiologic Technology professors for Academic year 2020-2021. Out of 58 respondents, Slovin's formula was employed arriving at 51 sample respondents who were randomly given an online research questionnaire instrument, representing 88.37 percent retrieval rate.

The research used a researcher-made questionnaire for the purpose of collecting the needed primary data. The first part included the level of technical capabilities, second parts was the utilization of Instructional Strategies and the third part include the level of learners' engagements which was measured using the Likert-Scale. The researcher made used of email and social media to give the letter of intent addressed to the dean of the selected school/ colleges in different higher educational institution for their approval for the conduct of the study. After gaining the permission, the researcher floated the online survey instrument to the respected respondents. To make sure that data gathered were precisely treated weighted mean was used to determine the respondents' level of technical capabilities, instructional strategies and level of learners' engagement in online learning. Descriptive statistics such as Pearson Product Moment of Correlation or Pearson- $r$ was used to ascertain if there is relationship between the respondents' technical capabilities, instructional strategies and learners' engagement in online learning.

\section{Results and Discussion}

Discussion on the technical capabilities, instructional strategies and learners' engagement in online learning is presented in the succeeding tables and textual presentations: 
INTERNATIONAL JOURNAL OF ACADEMIC RESEARCH IN PROGRESSIVE EDUCATION AND DEVELOPMENT

Vol. 10, No. 2, 2021, E-ISSN: 2226-6348 @ 2021 HRMARS

Table 1. The Respondents' Level of Technical Capabilities on Online Learning Instruction

\begin{tabular}{|c|c|c|c|}
\hline Indicators & $\begin{array}{l}\text { Weighted } \\
\text { Mean }\end{array}$ & $\begin{array}{l}\text { Verbal } \\
\text { Interpretation }\end{array}$ & Rank \\
\hline $\begin{array}{l}\text { 1. Properly connect main components, } \\
\text { configure, peripherals and install drivers } \\
\text { when required }\end{array}$ & 3.43 & $\begin{array}{l}\text { Highly } \\
\text { Capable }\end{array}$ & 7.5 \\
\hline $\begin{array}{l}\text { 2. Configure computer settings of various } \\
\text { software and hardware }\end{array}$ & 3.37 & $\begin{array}{l}\text { Highly } \\
\text { Capable }\end{array}$ & 10 \\
\hline $\begin{array}{l}\text { 3. Organize and manage computer files, } \\
\text { folders and directories }\end{array}$ & 3.67 & $\begin{array}{l}\text { Highly } \\
\text { Capable }\end{array}$ & 2 \\
\hline $\begin{array}{l}\text { 4. Use online and offline help facilities for } \\
\text { trouble-shooting, maintenance and } \\
\text { update of application }\end{array}$ & 3.41 & $\begin{array}{l}\text { Highly } \\
\text { Capable }\end{array}$ & 9 \\
\hline $\begin{array}{l}\text { 5. Format text, control margin, layout and } \\
\text { tables }\end{array}$ & 3.49 & $\begin{array}{l}\text { Highly } \\
\text { Capable }\end{array}$ & 6 \\
\hline $\begin{array}{l}\text { 6. Use word processor to enter and edit text } \\
\text { and images }\end{array}$ & 3.61 & $\begin{array}{l}\text { Highly } \\
\text { Capable }\end{array}$ & 4 \\
\hline $\begin{array}{l}\text { 7. Use a presentation package to add text } \\
\text { and sequence a presentation }\end{array}$ & 3.61 & $\begin{array}{l}\text { Highly } \\
\text { Capable }\end{array}$ & 4 \\
\hline $\begin{array}{l}\text { 8. Stitch together video footages and sound- } \\
\text { tracks and add simple enhancements- } \\
\text { transitions, titles and etc. }\end{array}$ & 3.43 & $\begin{array}{l}\text { Highly } \\
\text { Capable }\end{array}$ & 7.5 \\
\hline $\begin{array}{l}\text { 9. Effectively use search engines, web } \\
\text { directories and benchmarks }\end{array}$ & 3.61 & $\begin{array}{l}\text { Highly } \\
\text { Capable }\end{array}$ & 4 \\
\hline $\begin{array}{l}\text { 10. Download and install relevant applications } \\
\text { including freeware, shareware, updates, } \\
\text { viewers and support applications. }\end{array}$ & 3.73 & $\begin{array}{l}\text { Highly } \\
\text { Capable }\end{array}$ & 1 \\
\hline Average & 3.54 & $\begin{array}{l}\text { Highly } \\
\text { Capable }\end{array}$ & \\
\hline
\end{tabular}

Legend: (Strongly Agree/ Highly Capable - 4, Agree/Capable - 3, Slightly Agree/ Slightly Capable -2 , Disagree/Not Capable -1 )

As seen in Table 1, for The Respondents' level of Technical Capabilities on Online Learning Instruction indicator 10 "Download and install relevant applications including freeware, shareware, updates, viewers and support applications." got a weighted mean of 3.73 was interpreted as Highly Capable and was rank 1. Indicator 3 "Organize and manage computer files, folders and directories." had a weighted mean of 3.67 was interpreted as Highly Capable and was rank 2., indicator 6,7 and 9 "Use word processor to enter and edit text and images." And Use a presentation package to add text and sequence a presentation, effectively use search engines, web directories and benchmarks with a weighted mean of 3.61 were interpreted as Highly Capable and was rank 4. 
On the other hand, indicator 5 which states that "Format text, control margin, layout and tables." obtained a weighted mean of 3.49 was interpreted as Highly Capable and was rank 6. Indicator 1 and 8 "Properly connect main components, configure, peripherals and install drivers when required" and Stitch together video footages and sound-tracks and add simple enhancements- transitions, titles and etc. which had a weighted mean of 3.43 was interpreted as highly capable and was rank 7.5. indicator 4 "Use online and offline help facilities for troubleshooting, maintenance and update of application" with a weighted mean of 3.41 was interpreted as highly capable and was rank 9. Lastly indicator 2" Configure computer settings of various software and hardware" with a weighted mean of 3.37 was interpreted as highly capable and was rank 10.

To sum up, an average weighted mean of 3.54 revealed that the respondents had highly capable on the Technical Capabilities on Online Learning Instruction. This means that the in creating an efficient and effective digital classroom requires online teachers to develop exceptional technical capabilities skills. Teachers should be able to demonstrate proficiency in Downloading and install relevant applications including freeware, shareware, updates, viewers and support applications. Ability to troubleshoot minor technical issues and refer to technical support personnel when necessary. Likewise, full knowledge of accessibility requirements for technology in the classroom and online instruction are needed.

The findings of the study support Beetz, et.al (2016) stated that Integrating innovative technology during classroom practices inevitably demands teachers to acquire new technological capabilities and pedagogical skills. This includes Organize and manage computer files, folders and directories, properly connect main components, configure, peripherals and install drivers when required. This also includes the effective use search engines, web directories and benchmarks. 
INTERNATIONAL JOURNAL OF ACADEMIC RESEARCH IN PROGRESSIVE EDUCATION AND

DEVELOPMENT

Vol. 10, No. 2, 2021, E-ISSN: 2226-6348 @ 2021 HRMARS

Table 2. The Respondents' Utilization of Instructional Strategies on Online Learning Instruction

\begin{tabular}{|c|c|c|c|}
\hline Indicators & Weighted Mean & $\begin{array}{l}\text { Verbal } \\
\text { Interpretation }\end{array}$ & Rank \\
\hline $\begin{array}{l}\text { 1. Use appropriately slide presentation, } \\
\text { video audio and other media in an } \\
\text { online classroom }\end{array}$ & 3.80 & Very Often & 2 \\
\hline $\begin{array}{l}\text { 2. Teach students to use various } \\
\text { multimedia materials for the reports } \\
\text { and class presentations }\end{array}$ & 3.63 & Very Often & 7 \\
\hline $\begin{array}{l}\text { 3. Use various synchronous and } \\
\text { asynchronous communication tools } \\
\text { (email, chat, whiteboard, forums and } \\
\text { blogs) }\end{array}$ & 3.82 & Very Often & 1 \\
\hline $\begin{array}{l}\text { 4. Design rubrics for assessing student } \\
\text { performance in the use of various } \\
\text { technologies }\end{array}$ & 3.39 & Very Often & 10 \\
\hline $\begin{array}{l}\text { 5. Use of electronic means of } \\
\text { administering quizzes and examinations }\end{array}$ & 3.73 & Very Often & 3.5 \\
\hline $\begin{array}{l}\text { 6. Explore the use of electronic assessment } \\
\text { tools like submission of projects via } \\
\text { email or online facilities }\end{array}$ & 3.73 & Very Often & 3.5 \\
\hline $\begin{array}{l}\text { 7. Encourage students to do data analysis, } \\
\text { problem solving, decision making and } \\
\text { exchange of ideas and information }\end{array}$ & 3.61 & Very Often & 8 \\
\hline $\begin{array}{l}\text { 8. Facilitate cooperative online learning } \\
\text { and exchange of ideas and information }\end{array}$ & 3.69 & Very Often & 5.5 \\
\hline $\begin{array}{l}\text { 9. Make effective class presentations using } \\
\text { the slides and LCD projector }\end{array}$ & 3.69 & Very Often & 5.5 \\
\hline $\begin{array}{l}\text { 10. Make computation, use formula and } \\
\text { create graphs using spreadsheets }\end{array}$ & 3.51 & Very Often & 9 \\
\hline Average & 3.66 & Very Often & \\
\hline
\end{tabular}

Legend: (Strongly Agree/ Very Often - 4, Agree/Often - 3, Slightly Agree/ Rarely - 2, Disagree/Never - 1)

As shown in Table 2, for the respondents' utilization of Instructional Strategies on Online Learning Instruction indicator 3 which states that Use various synchronous and asynchronous communication tools (email, chat, whiteboard, forums and blogs." with a weighted mean of 3.82 was interpreted as very often and was rank 1 . Indicator 1 "Use appropriately slide presentation, video audio and other media in an online classroom." obtained a weighted mean of 3.80 which was interpreted as very often and was rank 2. Indicator 5 and 6 ". Use of electronic means of administering quizzes and examinations." Explore the use of electronic assessment tools like 
submission of projects via email or online facilities with a weighted mean of 3.73 was interpreted very often and was rank 3.5

On the other hand, indicator 8 and 9 which states "Facilitate cooperative online learning and exchange of ideas and information." Make effective class presentations using the slides and LCD projector got a weighted mean of 3.69 was interpreted very often and was rank 5.5 Indicator 2 "Teach students to use various multimedia materials for the reports and class presentations." with a weighted mean of 3.63was interpreted as very often and was rank 7. indicator 7" Encourage students to do data analysis, problem solving, decision making, and exchange of ideas and information obtained a weighted mean of 3.61 was interpreted as very often and was rank 8. Indicator 10" Make computation, use formula and create graphs using spreadsheets." obtained a weighted mean of 3.51 was interpreted as very often and was rank 9. Lastly indicator4" Design rubrics for assessing student performance in the use of various technologies". obtained a weighted mean of 3.39 was interpreted as very often and was rank 10.

To sum up, the average weighted mean of 3.66 revealed that the Respondents' frequently utilize the different Instructional Strategies on Online Learning Instruction. This means that in Employing Multimodal Strategies in Online Teaching several strategies were explore especially the use various synchronous and asynchronous activities.

The findings of the study support the research of Gillett-Swan (2017) which stated that the importance of creating a learning community, providing personalized experiences to the students, designing courses using proper technology, and forming supportive community (for both students and faculties) to learn from each other. Moreover, on-line strategies such as monitoring discussion regularly to direct the discussions towards the intention of creating mastery of the content and Incorporate collaborative works in the beginning and assignments that involve arguments like debating etc. can occur when the learning community is formed this will lead to reduce chances of conflicts and will Create positive social environment in the class, Positive learning environment denotes higher level of learning and learner satisfaction is achieved. 
INTERNATIONAL JOURNAL OF ACADEMIC RESEARCH IN PROGRESSIVE EDUCATION AND

DEVELOPMENT

Vol. 10, No. 2, 2021, E-ISSN: 2226-6348 @ 2021 HRMARS

Table 3. The Learners' Engagements on Online Learning Instruction as Perceived by the Respondents

\begin{tabular}{|c|c|c|c|}
\hline Indicators & Weighted Mean & Verbal & Rank \\
\hline $\begin{array}{l}\text { 1. Engage in analyzing information, } \\
\text { comparing and contrasting ideas using } \\
\text { computers }\end{array}$ & 3.43 & Highly Engage & 8 \\
\hline $\begin{array}{l}\text { 2. Students use multiple sources of } \\
\text { information (internet, references etc. }\end{array}$ & 3.63 & Highly Engage & 3.5 \\
\hline $\begin{array}{l}\text { 3. Interact with other students in the } \\
\text { course using emails and WebCT }\end{array}$ & 3.51 & Highly Engage & 7 \\
\hline $\begin{array}{l}\text { 4. Engage in representing understanding } \\
\text { of concepts by using computer }\end{array}$ & 3.63 & Highly Engage & 3.5 \\
\hline $\begin{array}{l}\text { 5. Communicate with the professors } \\
\text { using emails and WebCT }\end{array}$ & 3.69 & Highly Engage & 1 \\
\hline $\begin{array}{l}\text { 6. Collaborate within classmates on } \\
\text { shared learning projects }\end{array}$ & 3.61 & Highly Engage & 5 \\
\hline $\begin{array}{l}\text { 7. Use the web to share digital files } \\
\text { related to the course (sharing photos, } \\
\text { audio files, digital documents, } \\
\text { websites etc.) }\end{array}$ & 3.67 & Highly Engage & 2 \\
\hline $\begin{array}{l}\text { 8. Use an ePortfolio system to record the } \\
\text { achievements for future use beyond } \\
\text { the course of the studies }\end{array}$ & 3.37 & Highly Engage & 9 \\
\hline $\begin{array}{l}\text { 9. Use a personal dashboard on the } \\
\text { university intranet to access all the } \\
\text { academic information related to } \\
\text { courses, grades and etc. }\end{array}$ & 3.55 & Highly Engage & 6 \\
\hline $\begin{array}{l}\text { 10. Design and build web pages as part of } \\
\text { the course }\end{array}$ & 2.90 & Engage & 10 \\
\hline Average & 3.90 & $\begin{array}{l}\text { Highly } \\
\text { Engage }\end{array}$ & \\
\hline
\end{tabular}

Legend: (Strongly Agree/ Highly Engage - 4, Agree/Engage - 3, Slightly Agree/ Slightly Engage 2, Disagree/Unengaged -1 )

As shown in Table 3, for the Learners' level of Engagements on Online Learning Instruction as Perceived by the Respondents indicator 5 which states that Communicate with the professors using emails and WebCT." with a weighted mean of 3.69 was interpreted as highly engage and was rank 1. Indicator 7 "Use the web to share digital files related to the course (sharing photos, audio files, digital documents, websites etc.)." obtained a weighted mean of 3.67 which was interpreted as highly engage and was rank 2. Indicator 2 and 4 ". Students use multiple sources 
of information (internet, references etc." Engage in representing understanding of concepts by using computer with a weighted mean of 3.63 was interpreted highly engage and was rank 3.5

On the other hand, indicator 6 which states "Collaborate within classmates on shared learning projects got a weighted mean of 3.61 was interpreted highly engage and was rank 5. Indicator 9 "Use a personal dashboard on the university intranet to access all the academic information related to courses, grades and etc.." with a weighted mean of 3.55 was interpreted as highly engage and was rank 6 . Indicator 3" Interact with other students in the course using emails and WebCT obtained a weighted mean of 3.51 was interpreted as highly engage and was rank 7. Indicator 1" Engage in analyzing information, comparing and contrasting ideas using computers." obtained a weighted mean of 3.43 was interpreted as highly engage and was rank 8. Indicator 8" Use an eportfolio system to record the achievements for future use beyond the course of the studies" obtained a weighted mean of 3.37 was interpreted as highly engage and was rank 9 Lastly indicator 10, Design and build web pages as part of the course," obtained a weighted mean of 2.90 was interpreted as engage and was rank 10.

To sum up, the average weighted mean of 3.90 revealed that the level of learners' engagements on online learning Instruction as perceived by the respondents were highly engage in any aspect on online learning instructions techniques and strategies. This means that the students were assertive and fascinating on different online learning practices.

The findings of the study support the research of Zhou. et. al (2017) studied the role of learning engagement in technology mediated learning and its effect on learning effectiveness and satisfaction, and their experimental data showed that the effects of technology-mediated learning were mediated by learning engagement, learning engagement had a positive effect on learning effectiveness whether in face-to-face learning or technology-mediated learning. When students are more engaged in learning, they will gain more in their learning activities. When students are less engaged in learning, they will find it difficult to engage in learning roles and thus gain little in learning activities. In online learning, whether students can participate in learning activities and whether they can participate in learning activities are the most critical and most important factors to ensure the learning effectiveness. The essence of online learning is the continuous development of students' cognitive level, and to acquire effective learning, students need to participate actively in learning. 
INTERNATIONAL JOURNAL OF ACADEMIC RESEARCH IN PROGRESSIVE EDUCATION AND

DEVELOPMENT

Vol. 10, No. 2, 2021, E-ISSN: 2226-6348 @ 2021 HRMARS

Table 4. Relationship between the Respondents Level of Technical Capability and Instructional Strategies on Online Learning Instruction

\begin{tabular}{llll}
\hline Indicators & Pearson r & p-value & Interpretation \\
\hline $\begin{array}{l}\text { Respondents Technical } \\
\text { Capability and Instructional }\end{array}$ & 0.702 & & \\
$\begin{array}{l}\text { Strategies on Online Learning } \\
\text { Instruction }\end{array}$ & High correlation & 0.000 & Significant \\
Significant @ 0.01 & & & \\
\hline
\end{tabular}

As shown in the table there was a significant relationship between the respondents' level of technical capability and their instructional strategies on online learning instruction. This implies that the better the technical capability of the respondents the better their instructional strategies on online learning instruction.

As shown in Table 4, for the relationship between the Respondents level of Technical Capability and Instructional Strategies on Online Learning Instruction, the p-value of 0.000 was obtained which was lower than 0.01 level of significance; this showed that there was a significant relationship between the respondents' perception of the technical capability and their attitude in using instructional strategies towards online learning instruction. This means the higher the respondent's level of the technical capability, the more they become assertive in using instructional strategies on online learning instruction.

The findings of the study support the research of Maher D. (2019) cited that technology has positively impact the design of instructional strategies since technical competencies are specific to the use of the technology, technical knowledge and proficiency in the use of current technology, the ability to troubleshoot technology issues, and the ability to assist learners effectively the faculty need to evaluate the instructional effectiveness and value of learning materials for a course, as well as ensure those selected align to the given context, curriculum, and outcomes. Faculty also adjust materials based on credibility, clarity, validity, reliability, accuracy, currency, accessibility, usability, and quality of course resources Materials may include text; audio, video, and other delivery media; and simulations to aid student understanding, interpretation, and internalization of new information. 
INTERNATIONAL JOURNAL OF ACADEMIC RESEARCH IN PROGRESSIVE EDUCATION AND

DEVELOPMENT

Vol. 10, No. 2, 2021, E-ISSN: 2226-6348 @ 2021 HRMARS

Table 5. Relationship between the Respondents Level of Technical Capability and Level of Learners' Engagement on Online Learning Instruction

\begin{tabular}{llll}
\hline Indicators & Pearson r & p-value & Interpretation \\
\hline Respondents Technical & & & \\
Capability and Learners' & 0.521 & 0.000 & Significant \\
$\begin{array}{l}\text { Engagement on Online Learning } \\
\text { Instruction }\end{array}$ & Moderate correlation & & \\
Significant @ 0.01 & & & \\
\hline
\end{tabular}

As shown in Table 5, for the relationship between the Respondents level of Technical Capability and level of Learners engagement on Online Learning Instruction, the p-value of 0.000 was obtained which was lower than 0.01 level of significance; this showed that there was a significant relationship between the respondents' perception of the technical capability and learner's engagement on online instruction. This means the higher the respondent's level of technical capability, the higher is the level of learners' engagement in on online learning instruction.

The findings of the study support the research of Halverson. et. al (2017) cited that due to the growing use of online and blended modalities, and the ever-increasing use of digital tools by students, it has been suggested that engagement is particularly relevant to the field of TEL and have showed that university students engage in learning in a mobile, flexible and multimodal way by using the affordances of different technologies and by employing digital skills related to multimodal literacy. Thus, the possession of certain digital skills creates suitable conditions for productive engagement with learning technologies.

Table 6. Relationship between the Respondents Instructional Strategies and Level of Learners' Engagement on Online Learning Instruction

\begin{tabular}{llll}
\hline Indicators & Pearson r & p-value & Interpretation \\
\hline Respondents Instructional & & & \\
Strategies and Learners' & 0.633 & 0.000 & Significant \\
Engagement on Online Learning & Moderate correlation & & \\
Instruction & & & \\
Significant @ 0.01 & & \\
\hline
\end{tabular}

As shown in Table 6, for the relationship between the Respondents Instructional Strategies and level of Learners engagement on Online Learning Instruction, the p-value of 0.000 was obtained which was lower than 0.01 level of significance; this showed that there was a significant relationship between the respondents' instructional strategies and level of learners' engagement on online instruction. This means the more the respondents are confident in the 
utilization of instructional strategies, the higher the level of learners' engagement on online learning instruction.

The findings of the study support the research of Chen, et. al., (2017) Online classes need efficient strategies to provide effective learning experiences to the learners. Strategies like motivation plays crucial role in online class environment. The motivated students tend to have engaging learning experiences as they spend time viewing and reviewing the course content. Providing information in small chunks, placing important information in the center of the screen, explaining why the learners are given specific information and enabling learners to read (even figures) from left to right are some cognitive strategies that can be practiced in online classes and will engage the learner.

\section{Conclusion}

The Radiologic Technology professors were very confident and constructive in terms of technical capabilities and instructional strategies. The learners' engagement in online learning instruction as perceived by the respondents was high that makes the learning more meaningful and enjoyable. This shows that the professors need to integrate innovative technology from classroom practices to online learning that inevitable demands to acquire new technological capabilities and pedagogical skills during online instruction.

Additionally, an understanding of the significant relationship between the level of technical capabilities, instructional strategies and their level of learners' engagement in online learning instruction shows the higher the respondents' level of technical capability, the more they utilize instructional strategies that would make the respondents motivated in online learning. The results signify that Radiologic Technology professors must possess certain digital skills to create suitable conditions for productive engagement on learning technologies. The proposed online learning instruction framework was made based on findings of the study. 
INTERNATIONAL JOURNAL OF ACADEMIC RESEARCH IN PROGRESSIVE EDUCATION AND DEVELOPMENT

Vol. 10, No. 2, 2021, E-ISSN: 2226-6348 @ 2021 HRMARS

Table 7: The Propose Online Instructional Framework for Radiologic Technology Program

\begin{tabular}{|c|c|c|}
\hline $\begin{array}{l}\text { Framework } \\
\text { Elements }\end{array}$ & $\begin{array}{c}\text { Mediating Web-Based } \\
\text { Tools }\end{array}$ & Intervention of Teaching Strategies \\
\hline $\begin{array}{c}\text { Content } \\
\text { (primary drivers of } \\
\text { instruction and } \\
\text { ways in which } \\
\text { content can be } \\
\text { delivered \& } \\
\text { presented) }\end{array}$ & $\begin{array}{l}\text { Online class, } \\
\text { synchronous \& } \\
\text { asynchronous } \\
\text { discussion, eLearning } \\
\text { resources }\end{array}$ & 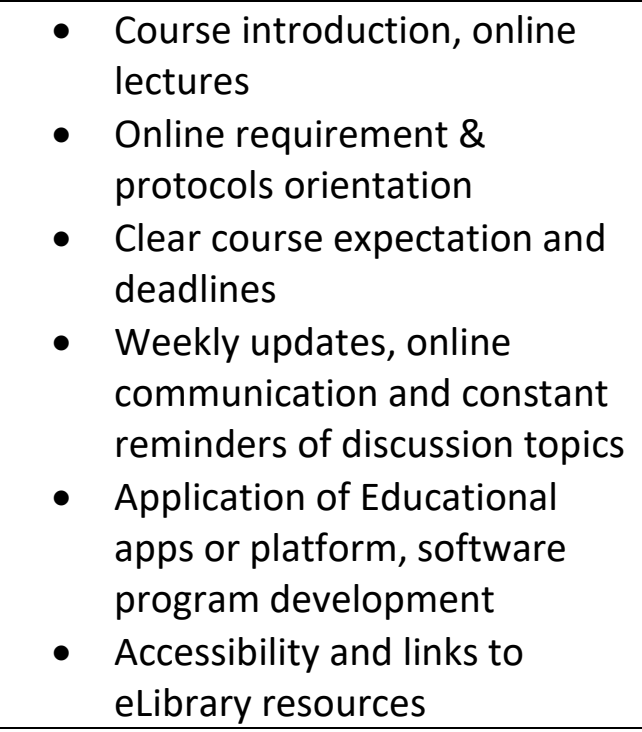 \\
\hline $\begin{array}{l}\text { Facilitated Action } \\
\text { (selection of tools } \\
\text { and activities that } \\
\text { afford mediate } \\
\text { interaction and } \\
\text { participation) }\end{array}$ & $\begin{array}{l}\text { Online photos, } \\
\text { ePortfolios, } \\
\text { synchronous \& } \\
\text { asynchronous } \\
\text { discussion, web links, } \\
\text { Forum }\end{array}$ & $\begin{array}{l}\text { - Application and use of } \\
\text { different scenarios, and } \\
\text { situations to generate dialogs, } \\
\text { group accountability and } \\
\text { organized group positioning } \\
\text { ideas } \\
\text { - Peer feedback in any group } \\
\text { activity and dialogues } \\
\text { - Use of online learning } \\
\text { laboratory activity } \\
\text { Video options, screen } \\
\text { recordings, digital text options, } \\
\text { Use a word } \\
\text { processing program, navigate } \\
\text { the Internet, and download } \\
\text { software } \\
\text { Accessibility and links to any } \\
\text { technical and eLibrary } \\
\text { resources }\end{array}$ \\
\hline $\begin{array}{l}\text { Goal-directed } \\
\text { (selection of } \\
\text { authentic and } \\
\text { relevant tasks that }\end{array}$ & $\begin{array}{l}\text { Synchronous \& } \\
\text { asynchronous } \\
\text { discussion, web links, } \\
\text { web-page }\end{array}$ & $\begin{array}{l}\text { - Use of different scenarios, and } \\
\text { circumstances to generate } \\
\text { dialogs on various course } \\
\text { related ideas } \\
\text { - Use of a variety group and } \\
\text { individual task in the course }\end{array}$ \\
\hline
\end{tabular}


Vol. 10, No. 2, 2021, E-ISSN: 2226-6348 @ 2021 HRMARS

\begin{tabular}{|c|c|c|}
\hline $\begin{array}{l}\text { situate activity to } \\
\text { accomplish } \\
\text { particular goals) }\end{array}$ & $\begin{array}{l}\text { announcements. } \\
\text { elearning resources, } \\
\text { Forum, Online photos, }\end{array}$ & $\begin{array}{l}\text { discussions, assessment and } \\
\text { activity in different } \\
\text { pedagogical purposes } \\
\text { - Use of different educational } \\
\text { media, digital text and } \\
\text { software options } \\
\text { - Weekly updates, online } \\
\text { communication and constant } \\
\text { reminders of discussion topics }\end{array}$ \\
\hline $\begin{array}{c}\text { Collaborative } \\
\text { Learning } \\
\text { (shared spaces for } \\
\text { interaction, } \\
\text { generating ideas, } \\
\text { collaboration and } \\
\text { team products) }\end{array}$ & $\begin{array}{l}\text { Online photos, } \\
\text { synchronous \& } \\
\text { asynchronous } \\
\text { discussion, web links, } \\
\text { Forum }\end{array}$ & $\begin{array}{l}\text { - Use of scenario, or situations } \\
\text { that support convincing } \\
\text { sharing of ideas, and } \\
\text { experiences for discussion } \\
\text { - } \quad \text { Peer feedback in any group } \\
\text { activity and dialogues } \\
\text { - Student presentation and } \\
\text { assessment with regard to the } \\
\text { given topic or activity } \\
\text { - Online lecturer monitoring, } \\
\text { mentoring, stating and linking } \\
\text { to student awareness's to } \\
\text { affirm their involvement on } \\
\text { the topic } \\
\text { - Hasty feedback to student } \\
\text { enquiries } \\
\text { Reminder and representations } \\
\text { of virtuous online } \\
\text { communication to faculty and } \\
\text { student } \\
\text { Make use of conflict resolution } \\
\text { mechanism } \\
\text { Use of different educational } \\
\text { media, digital text and } \\
\text { software options } \\
\text { eLibrary resources }\end{array}$ \\
\hline $\begin{array}{l}\text { Reflection } \\
\text { (require students } \\
\text { to reflect on what } \\
\text { they learn and to } \\
\text { share their }\end{array}$ & $\begin{array}{l}\text { Reflection paper, } \\
\text { Journals, Blogs/Vlogs }\end{array}$ & $\begin{array}{l}\text { - Sharing one's reflection to } \\
\text { others } \\
\text { - Make a pedagogical activity } \\
\text { that requires student to reflect } \\
\text { on what they have learn }\end{array}$ \\
\hline
\end{tabular}


Vol. 10, No. 2, 2021, E-ISSN: $2226-6348$ @ 2021 HRMARS

\begin{tabular}{|c|c|c|}
\hline $\begin{array}{l}\text { reflections with } \\
\text { faculty and } \\
\text { students) }\end{array}$ & & $\begin{array}{l}\text { - Blogs, Film Recording, Video } \\
\text { clips and journaling of } \\
\text { activities have evolved } \\
\text { appropriate tools \& other } \\
\text { aspects of course exercises }\end{array}$ \\
\hline $\begin{array}{l}\text { Evaluation } \\
\text { (allows more } \\
\text { seamless sharing } \\
\text { and records of } \\
\text { evaluation and } \\
\text { assessment } \\
\text { activities) }\end{array}$ & $\begin{array}{l}\text { Test questionnaire, } \\
\text { ePortfolios, } \\
\text { assignments, term } \\
\text { projects, return } \\
\text { demonstration, Video } \\
\text { Recording of activities }\end{array}$ & $\begin{array}{l}\text { - Giving of test examination, } \\
\text { assignments, and other } \\
\text { formative assessment tool } \\
\text { - Term paper, case study } \\
\text { presentation, video and audio } \\
\text { recording } \\
\text { - ePortfolio presentation of } \\
\text { images, weekly class } \\
\text { discussion on discussion board } \\
\text { or video } \\
\text { Assessment and review of } \\
\text { teaching method, style, work } \\
\text { and what did not work in } \\
\text { online class }\end{array}$ \\
\hline
\end{tabular}

Using the framework of Khoo \& Cowie (2020); Picciano (2017) a collaborative approached was adopted. This approached was taken to Jones \& Simon (1991) as cited by Khoo, E., \& Cowie, B. (2020) the negotiated intervention strategy framed and translated the pedagogical framework into teaching strategies. A summary of intervention teaching strategies, as well as the mediating web-based tools were adapted in the masters Research Method course is shown in table 7 in which can be propose as a framework for online learning instruction on Radiologic Technology Education.

The above proposed framework for online learning instruction was anticipated in order to guide the Radiologic Technology educators on to what was needed to enhance with regards to the enhancement of technical capability, utilization of instructional materials and to augmented the commitment of the learners to online learning. The translating framework to practice was assumed to guide the development and implementation of a pedagogical intervention which was identified from the general literature that would improve the online student learning experiences as well as the teacher preparation on online learning instruction. The researcher was keen to adopt a framework that would be relevant and suited to the teachingand-learning context of the course (Cowie,et al 2020)

\section{Recommendations}

The present study has some limitations on the sample size which was used in the study since it was only limited to the Radiologic Technology professors on selected Higher Educational Institutions in Region 4A during academic year 2020-2021. To have a better understanding it is recommended to future researchers to conduct similar study considering the effectiveness of the propose online learning instruction framework in order to enhance the technical capability, 
Vol. 10, No. 2, 2021, E-ISSN: $2226-6348$ @ 2021 HRMARS

instructional strategies and learner's engagement in online learning instruction and to have broader information with regard to the factors studied in this research.

\section{References}

Abdi. (2018). Factors Influencing Master Of Education Students 'utilization Of ICT Integrated Resources In Their Studies erepository.uonbi.ac.ke

Admiraal, W., Vugt, F. van, Kranenburg, F., Koster, B., Smit, B., Weijers, S., \& Lockhorst, D. (2017). Preparing pre-service teachers to integrate technology into $\mathrm{K}-12$ instruction: Evaluation of a technology-infused approach. Technology, Pedagogy and Education, 26(1), 105-120. https://doi.org/10.1080/1475939X.2016.1163283

Akcaoglu, M., \& Lee, E. (2016). Increasing Social Presence in Online Learning through Small Group Discussions. The International Review of Research in Open and Distributed Learning, 17(3). https://doi.org/10.19173/irrodl.v17i3.2293

Albert, M. G. (2017). Entrepreneurship, innovation and regional performance: Application for the Spanish regions. Entrepreneurship \& Regional Development, 29(3-4), 271291. https://doi.org/10.1080/08985626.2016.1267805

Aldamen, H., Duncan, K., \& Ziegelmayer, J. L. (2018). Cumulative learning and sustained engagement in an introduction to accounting course. Asian Review of Accounting, 26(1), 19-38. https://doi.org/10.1108/ARA-03-2017-0036

Aldunate, R., Salinas, Á., Nussbaum, M., Herrera, O., \& Solarte, M. (2017). Factors affecting the adoption of information and communication technologies in teaching. Education and Information Technologies, 22(5), 2175-2196. https://doi.org/10.1007/s10639-016-95407

Allen, I. E., \& Seaman, J. (2017). Digital Compass Learning: Distance Education Enrollment Report 2017. In Babson Survey Research Group. Babson Survey Research Group. https://eric.ed.gov/?id=ED580868

Ali, M. (2020). Student Engagement and ICT: A Meta-Analysis. 7. http://shabdbooks.com/gallery/257-may2020.pdf.

Almekhlafi, A., Ismail, S., \& Al-Mekhlafy, M. (2017). Male and female language teachers' technology integration differences in elementary schools in the United Arab Emirates. International Journal of Research Studies in Educational Technology, 6. https://doi.org/10.5861/ijrset.2016.1521

Alt, D. (2018). Science teachers' conceptions of teaching and learning, ICT efficacy, ICT professional development and ICT practices enacted in their classrooms. Teaching and Teacher Education, 73, 141-150. https://doi.org/10.1016/j.tate.2018.03.020

Amemado, D., \& Manca, S. (2017). Learning from decades of online distance education: MOOCs and the Community of Inquiry framework. Journal of E-Learning and Knowledge Society, 13(2). https://www.learntechlib.org/p/180225/.

Andrade, H. L., \& Heritage, M. (2017). Using Formative Assessment to Enhance Learning, Achievement, and Academic Self-Regulation. Routledge.

Andressen, A., Earle, L., Kor, A.-L., \& Pattinson, C. (2019). An Evaluation of ICT Smart Systems to Reduce the Carbon Footprint. In K. Arai, R. Bhatia, \& S. Kapoor (Eds.), Intelligent Computing (pp. 263-274). Springer International 
INTERNATIONAL JOURNAL OF ACADEMIC RESEARCH IN PROGRESSIVE EDUCATION AND

DEVELOPMENT

Vol. 10, No. 2, 2021, E-ISSN: 2226-6348 @ 2021 HRMARS

Publishing. https://doi.org/10.1007/978-3-030-22871-2_20

Bandura, R. P., \& Lyons, P., (2020). Stimulating employee learning: The confluence of case-based and self-regulated learning. Industrial and Commercial Training, 52(3), 171183. https://doi.org/10.1108/ICT-12-2019-0109

Baturay, M. H., Gokcearslan, S., \& Ke, F. (2017). The relationship among pre-service teachers' computer competence, attitude towards computer-assisted education, and intention of technology acceptance. International Journal of Technology Enhanced Learning, 9(1), 1. https://doi.org/10.1504/IJTEL.2017.084084

Baydas, O., \& Goktas, Y. (2017). A model for preservice teachers' intentions to use ICT in future lessons. Interactive Learning Environments, 25(7), 930-

945. https://doi.org/10.1080/10494820.2016.1232277

Beetz, M., Bebler, D., Winkler, J., Worch, J.-H., Balint-Benczedi, F., Bartels, G., Billard, A., Bozcuoglu, A. K., Zhou Fang, Figueroa, N., Haidu, A., Langer, H., Maldonado, A., Ureche, A. L. P., Tenorth, M., \& Wiedemeyer, T. (2016). Open robotics research using webbased knowledge services. 2016 IEEE International Conference on Robotics and Automation (ICRA), 5380-5387. https://doi.org/10.1109/ICRA.2016.7487749

Belyh, A. (2020). List of Technical Skills for Resumes, Cover Letters, and Interviews. Cleverism. https://www.cleverism.com/list-of-technical-skills-for-resumes-cover-lettersand-interviews/

Bernard, M., Rohaeti, E., \& Bias Primandhika, R. (2019). Developing interactive learning media for school level mathematics through open-ended approach aided by visual basic application for excel. Journal on Mathematics Education, 10, 5968. https://doi.org/10.22342/jme.10.1.5391.59-68

Bibi, S., \& Khan, S. H. (2017). TPACK in action: A study of a teacher educator's thoughts when planning to use ICT. Australasian Journal of Educational Technology, 33(4), Article 4. https://doi.org/10.14742/ajet.3071

Bingimlas, D. K. A. (2017). Learning and Teaching with Web 2.0 Applications in Saudi K-12 Schools. The Turkish Online Journal of Educational Technology, 16(3), 16.

Bond, M. (2020). Digital transformation in German higher education: student and teacher perceptions and usage of digital media. Int J Educ Technol High Educ 15, 48 https://doi.org/10.1186/s41239-018-0130-1

Bond, M., Buntins, K., Bedenlier, S., Zawacki-Richter, O., \& Kerres, M. (2020). Mapping research in student engagement and educational technology in higher education: A systematic evidence map. International Journal of Educational Technology in Higher Education, 17(1), 2. https://doi.org/10.1186/s41239-019-0176-8

Borup, J., Graham, C. R., West, R. E., Archambault, L., \& Spring, K. J. (2020). Academic Communities of Engagement: An expansive lens for examining support structures in blended and online learning. Educational Technology Research and Development, 68(2), 807-832. https://doi.org/10.1007/s11423-020-09744-x

Bowtell, G. (2020) A team-teaching approach for blended learning: an experiment, Studies in Higher Education, DOI: 10.1080/03075079.2020.1817887

Bralić, A., \& Divjak, B. (2018). Integrating MOOCs in traditionally taught courses: Achieving 
INTERNATIONAL JOURNAL OF ACADEMIC RESEARCH IN PROGRESSIVE EDUCATION AND

DEVELOPMENT

Vol. 10, No. 2, 2021, E-ISSN: 2226-6348 @ 2021 HRMARS

learning outcomes with blended learning. International Journal of Educational Technology in Higher Education, 15(1), 2. https://doi.org/10.1186/s41239-017-0085-7

Caluza, L. J. B., Verecio, R. L., Funcion, D. G. D., Quisumbin, L. A., Gotardo, M.

A., Laurente, M. L. P., Cinco, J. C., \& Marmita, V. (2017). An Assessment of ICT Competencies of Public School Teachers: Basis for Community Extension Program. IOSR Journal of Humanities and Social Science, 22(03), 01-13. https://doi.org/10.9790/08372203040113

Castaño-Muñoz, J., Kalz, M., Kreijns, K., \& Punie, Y. (2018). Who is taking MOOCs for teachers' professional development on the use of ICT? A cross-sectional study from Spain. Technology, Pedagogy and Education, 27(5), 607624. https://doi.org/10.1080/1475939X.2018.1528997

Carbone, A., \& Hamilton, M. (2016). Pizza with university ICT students: What do students' expect employers want from them? Proceedings of the Australasian Computer Science Week Multiconference, 1-9. https://doi.org/10.1145/2843043.2843345

Chakraborty M. (2019) Sustainable strategies for making green image in University Libraries in Seven-Sister States, India: a study. Paper presented at: IFLA WLIC 2019 Athens, Greece - Libraries: dialogue for change in Session $156 \quad$ - $\quad$ Environment, Sustainability and Libraries.

Chen, F., Gorbunova, N. V., Masalimova, A. R., \& Bírová, J. (2017). Formation of ICT-Competence of Future University School Teachers. Eurasia Journal of Mathematics, Science and Technology Education, 13(8), 4765-4777. https://doi.org/10.12973/eurasia.2017.00963a

Chiou, S.-F., Su, H.-C., \& Huang, E.-W. (2017). [The Application of Information and Communication Technology (ICT) in Nursing Education]. Hu Li Za Zhi The Journal of Nursing, 64(6), 511. https://doi.org/10.6224/JN.000077

Cho, M.-H., Kim, Y., \& Choi, D. (2017). The effect of self-regulated learning on college students' perceptions of community of inquiry and affective outcomes in online learning. The Internet and Higher Education, 34, 1017. https://doi.org/10.1016/j.iheduc.2017.04.001

Cuban, S. (2017). The ICT-Based Networks of Highly Skilled Immigrant Women: "I Had Bigger Ambitions" (pp. 147-178). https://doi.org/10.1057/978-1-137-58644-5_5

Cubeles, A., \& Riu, D. (2018). The effective integration of ICTs in universities: The role of knowledge and academic experience of professors. Technology, Pedagogy and Education, 27(3), 339-349. https://doi.org/10.1080/1475939X.2018.1457978

Dalal, M., Archambault, L., \& Shelton, C. (2017). Professional Development for International Teachers: Examining TPACK and Technology Integration Decision Making. Journal of Research on Technology in Education, 49(3-4), 117133. https://doi.org/10.1080/15391523.2017.1314780

de Koster, S. (2017). Concept-guided development of classroom use of ICT: Concept-specific types of ICT use and their integration into teachers' practices. https://dare.uva.nl/search?identifier $=8718 c 16 d-072 c-4475-a 32 c-$ 16d38e7aadad

Doyle, L. (2020). Software-defined home offerings drive remote 
INTERNATIONAL JOURNAL OF ACADEMIC RESEARCH IN PROGRESSIVE EDUCATION AND

DEVELOPMENT

Vol. 10, No. 2, 2021, E-ISSN: $2226-6348$ @ 2021 HRMARS

productivity.SearchNetworking. https://searchnetworking.techtarget.com/tip/Softwaredefined-home-offerings-drive-remote-productivity

Drossel, K., Eickelmann, B., \& Gerick, J. (2017). Predictors of teachers' use of ICT in school - the relevance of school characteristics, teachers' attitudes and teacher collaboration. Education and Information Technologies, 22(2), 551573. https://doi.org/10.1007/s10639-016-9476-y

Dziuban, C., Graham, C. R., Moskal, P. D., Norberg, A., \& Sicilia, N. (2018).

Blended learning: The new normal and emerging technologies. International Journal of Educational Technology in Higher Education, 15(1), 3. https://doi.org/10.1186/s41239017-0087-5

Edwards, C., Whitelock, D., Okada, A., \& Holmes, W. (2018). Trust in online authentication tools for online assessment in both formal and informal contexts (L. Gómez Chova, A. López Martínez, \& I. Candel Torres, Eds.; pp. 3754-3762). IATED Academy. http://oro.open.ac.uk/58147/

Ekberg, S., \& Gao, S. (2018). Understanding Challenges of Using ICT in Secondary Schools in Sweden from Teachers' Perspective. International Journal of Information and Learning Technology, 35(1), 43-55. https://doi.org/10.1108/IJILT-01-2017-0007

Elvira, Q., Imants, J., Dankbaar, B., \& Segers, M. (2017). Designing Education for Professional Expertise Development. Scandinavian Journal of Educational Research, 61(2), 187-204. https://doi.org/10.1080/00313831.2015.1119729

Evbuomwan, O., Kanmodi, K. K., Nwafor, N. J., Omoruyi, E., \& Buowari, D. Y. (2020). Incorporating "ICT" Training into Undergraduate Medical Curriculum: An Online Survey assessing the opinions of Medical Students. Medical Journal of Zambia,47(3), 215222. https://www.ajol.info/index.php/mjz/article/view/205163

Farrell, O., \& Brunton, J. (2020). A balancing act: A window into online student engagement experiences. International Journal of Educational Technology in Higher Education, 17(1), 25. https://doi.org/10.1186/s41239-020-00199-x

Fernández-Cruz, F. J., Ernández-Díaz, M. J., \& Rodríguez-Mantilla, J. M. (2018). Diseño y validación de un instrumento de medida del perfil de formación docente en tecnologías de la información y comunicación. Revista Española de Pedagogía, 76(270). https://doi.org/10.22550/REP76-2-2018-03

Flavin, M., \& Quintero, V. (2018). UK higher education institutions' technology-enhanced learning strategies from the perspective of disruptive innovation. Research in Learning Technology, 26. https://doi.org/10.25304/rlt.v26.1987

Frolova, E., Ryabova, T., \& Rogach, O. (2018). Interactive technologies of forming the students" media competence: Opportunities and limitations of their use in Contemporary educational practice. Медиаобразование, 4, 2228. https://cyberleninka.ru/article/n/interactive-technologies-of-forming-the-studentsmedia-competence-opportunities-and-limitations-of-their-use-in-contemporaryeducational

Garbin Praničević, D., Spremić, M., \& Jaković, B. (2019). Technology and Educational Leadership: The Role of Leaders vs. National Education Policies. In Á. H. Ingpórsson, N. Alfirević, J. Pavičić, \& D. Vican (Eds.), Educational Leadership in Policy: Challenges and 
INTERNATIONAL JOURNAL OF ACADEMIC RESEARCH IN PROGRESSIVE EDUCATION AND

DEVELOPMENT

Vol. 10, No. 2, 2021, E-ISSN: 2226-6348 @ 2021 HRMARS

Implementation Within Europe (pp. 97-116). Springer International Publishing. https://doi.org/10.1007/978-3-319-99677-6_7

Gasaymeh, A.-M., AlJa'afreh, I. A., Al-Dmour, A., \& Alrub, M. A. (2016). Higher Education

Students' Preferences for Applying the Principles of Constructivism in Learning Programming Languages with the Use of ICTs. Journal of Studies in Education, 6(3), 168187. https://doi.org/10.5296/jse.v6i3.9780

Genlott, A. A., \& Grönlund, Å. (2016). Closing the gaps - Improving literacy and mathematics by ict-enhanced collaboration. Computers \& Education, 99, 6880. https://doi.org/10.1016/j.compedu.2016.04.004

Ghavifekr, S., Kunjappan, T., Ramasamy, L., \& Anthony, A. (n.d.). Teaching and Learning with ICT Tools: Issues and Challenges from Teachers' Perceptions. 4(2), 20.

Gilakjani P.(2016) Teaching Pronunciation of English with Computer Technology: A Qualitative Study. IJREE. 2018; 3 (2)URL: https://ijreeonline.com/article-1-119-en.html

Gilbert, J. K., Jong, O. de, Justi, R., Treagust, D. F., \& Driel, J. H. van (Eds.). (2018). Chemical Education: Towards Research-based Practice. Springer Netherlands. https://doi.org/10.1007/0-306-47977-X

Gillett-Swan, J. (2017). Supporting and Engaging the Isolated Learner. Journal of Learning Design, 10(1), 11. https://files.eric.ed.gov/fulltext/EJ1127718.pdf.

Goldhammer, F., Gniewosz, G., \& Zylka, J. (2016). ICT Engagement in Learning Environments. In S. Kuger, E. Klieme, N. Jude, \& D. Kaplan (Eds.), Assessing Contexts of Learning: An International Perspective (pp. 331-351). Springer International Publishing. https://doi.org/10.1007/978-3-319-45357-6_13

Gudmundsdottir, G. B., \& Hatlevik, O. E. (2018). Newly qualified teachers' professional digital competence: Implications for teacher education. European Journal of Teacher Education, 41(2), 214-231. https://doi.org/10.1080/02619768.2017.1416085

Halverson, L. R., Spring, K. J., Huyett, S., Henrie, C. R., \& Graham, C. R. (2017). Blended Learning Research in Higher Education and K-12 Settings. In M. J. Spector, B. B. Lockee, \& M. D. Childress (Eds.), Learning, Design, and Technology: An International Compendium of Theory, Research, Practice, and Policy (pp. 1-30). Springer International Publishing. https://doi.org/10.1007/978-3-319-17727-4_31-1

Harasim, L. (n.d.). Learning Theory and Online Technologies. Routledge \& CRC Press. Retrieved May 6, 2021, from https://www.routledge.com/Learning-Theory-and-OnlineTechnologies/Harasim/p/book/9781138860001

Hasse, C., Trentemøller, S., \& Sorenson, J. (2019). Special Issue on Ethnography in Human-Robot Interaction Research. Paladyn, Journal of Behavioral Robotics, 10(1), 180181. https://doi.org/10.1515/pjbr-2019-0015

Hemmat, M., Ayatollahi, H., Maleki, M., \& Saghafi, F. (2019). A Review of Future Studies in the Field of Health Information Technology. Journal of Health and Biomedical Informatics, 6(1), 68-77. http://jhbmi.ir/article-1-305-en.html

Herbert, N. (2017). Impact of Student Engagement on First Year ICT Performance. 2017 International Conference on Computational Science and Computational Intelligence (CSCI), 1085-1090. https://doi.org/10.1109/CSCI.2017.189

Holmberg, J., Fransson, G., \& Fors, U. (2018). Teachers' pedagogical reasoning and 
reframing of practice in digital contexts. The International Journal of Information and Learning Technology, 35(2), 130-142. https://doi.org/10.1108/IJILT-09-2017-0084

Hrastinski, S., Olofsson, A. D., Arkenback, C., Ekström, S., Ericsson, E., Fransson, G., Jaldemark, J., Ryberg, T., Öberg, L.-M., Fuentes, A., Gustafsson, U., Humble, N., Mozelius, P., Sundgren, M., \& Utterberg, M. (2019). Critical Imaginaries and Reflections on Artificial Intelligence and Robots in Postdigital K-12 Education. Postdigital Science and Education, 1(2), 427445. https://doi.org/10.1007/s42438-019-00046-x

Hrastinski, S. (2021). Informing designs for learning when shifting to digital.

Educational Technology Research and Development, 69(1), 285-288. https://doi.org/10.1007/s11423-020-09894-y

Hughes, H., Dezuanni, M., \& Foth, M. (n.d.). Digital Participation through Social Living Labs-1st Edition. Retrieved May 6, 2021, from https://www.elsevier.com/books/digitalparticipation-through-social-living-labs/dezuanni/978-0-08-102059-3

Hu X et,al (2018). The Effectiveness of Customer Education: evaluating synchronous and asynchronous e-learning technologies. In: British Academy of Management Conference Proceedings 2018, 04-06 Sep 2018, Bristol, UK

Iredale, A., Stapleford, K., Tremayne, D., Farrell, L., Holbrey, C., \& Sheridan-Ross, J. (2020). A review and synthesis of the use of social media in initial teacher education. Technology, Pedagogy and Education, 29(1), 1934. https://doi.org/10.1080/1475939X.2019.1693422

Jimoyiannis, A., \& Roussinos, D. (2017). Students' collaborative patterns in a wiki-authoring project: Towards a theoretical and analysis framework. Journal of Applied Research in Higher Education, 9(1), 24-39. https://doi.org/10.1108/JARHE-05-2016-0034

Joksimović, S., Kovanović, V., \& Dawson, S. (2019, July). The Journey of Learning Analytics (pp. 3763) I herdsa.org.au. https://www.herdsa.org.au/herdsa-review-higher-education-vol6/37-63

Jones, B. (2020). The Experiences of Elementary Teachers Regarding Technology Integration in the Classroom. Walden Dissertations and Doctoral Studies. https://scholarworks.waldenu.edu/dissertations/8065

Karaseva, A. (2016). Pedagogy of Connection. In O. Erstad, K. Kumpulainen, Å. Mäkitalo, K. C. Schrøder, P. Pruulmann-Vengerfeldt, \& T. Jóhannsdóttir (Eds.), Learning across Contexts in the Knowledge Society (pp. 225-240). SensePublishers. https://doi.org/10.1007/97894-6300-414-5_12

Kaufman, D., \& Ireland, A. (2016). Enhancing Teacher Education with Simulations. TechTrends, 60(3), 260-267. https://doi.org/10.1007/s11528-016-0049-0

Kebritchi, M., Lipschuetz, A., \& Santiague, L. (2017). Issues and Challenges for Teaching Successful Online Courses in Higher Education: A Literature Review. Journal of Educational Technology Systems, 46, 4-29. https://doi.org/10.1177/0047239516661713

Kim, C. M. (2019). Defining E-leadership as Competence in ICT-Mediated Communications: An Exploratory Assessment https://doi.org/10.1111/puar.12980

King, B., Hammond, T., \& Harrington, J. (n.d.). Disruptive Technology: Economic Consequences of Artificial Intelligenceand the Robotics Revolution. Retrieved May 6, 2021, from http://nabusinesspress.homestead.com/JSIS/JSIS12-2/KingBA_abstract.html 
INTERNATIONAL JOURNAL OF ACADEMIC RESEARCH IN PROGRESSIVE EDUCATION AND

DEVELOPMENT

Vol. 10, No. 2, 2021, E-ISSN: 2226-6348 @ 2021 HRMARS

Kirkwood, A., \& Price, L. (2016). Technology-Enabled Learning Implementation Handbook. Commonwealth of Learning (COL). http://oasis.col.org/handle/11599/2363

Khoo, E., \& Cowie, B. (2020). A Framework for Developing and Implementing an Online Learning Community. 13.

Kollias, V., Davaris, A., Daropoulos, A., \& Zaganas, K. (2017). Using a ResearchBased Learning Environment's Appropriation, as the Context for a Professional Development Intervention in ICT Integration in the Classroom (pp. 59-75). https://doi.org/10.1007/978-3-319-34127-9_5

Kubota, K., Yamamoto, R., \& Morioka, H. (2018). Promoting ICT education in developing countries: Case Study in the Philippine.

Kucuk, S., \& Richardson, J. C. (2019). A Structural Equation Model of Predictors of Online Learners' Engagement and Satisfaction. Online Learning, 23(2), 196-216.

Kuger, S., Klieme, E., Jude, N., \& Kaplan, D. (Eds.). (2016). Assessing Contexts of Learning: An International Perspective. Springer International Publishing. https://doi.org/10.1007/978-3-319-45357-6

Kwok, D., \& Yang, S. (2017). Evaluating the intention to use ICT collaborative tools in a social constructivist environment. International Journal of Educational Technology in Higher Education, 14(1), 32. https://doi.org/10.1186/s41239-017-0070-1

Larosiliere, G. D., McHaney, R., \& Kobelsky, K. (2016). The Effects of IT Management on Technology Process Integration. Journal of Computer Information Systems, 56(4), 341351. https://doi.org/10.1080/08874417.2016.1164494

Lee, J., \& Fedorowicz, J. (2018). Identifying Issues for the Bright ICT Initiative: A Worldwide Delphi Study of IS Journal Editors and Scholars. Communications of the Association for Information Systems, 42(1). https://doi.org/10.17705/1CAIS.04211

Liu, H.-Y., Eleta, I., Kobernus, M., \& Cole-Hunter, T. (2016). Analysis of Public Interest in Environmental Health Information: Fine Tuning Content for Dissemination via Social Media. In A. Satsiou, G. Panos, I. Praggidis, S. Vrochidis, S. Papadopoulos, C. Keratidis, P. Syropoulou, \& H.-Y. Liu (Eds.), Collective Online Platforms for Financial and Environmental Awareness (pp. 129-146). Springer International

Publishing. https://doi.org/10.1007/978-3-319-50237-3_6

Liu, Q., Geertshuis, S., \& Grainger, R. (2020). Understanding academics' adoption of learning technologies: A systematic review. Computers \& Education, 151, 103857. https://doi.org/10.1016/j.compedu.2020.103857

Liu, H., Lin, C.-H., \& Zhang, D. (2017). Pedagogical beliefs and attitudes toward information and communication technology: A survey of teachers of English as a foreign language in China. Computer Assisted Language Learning, 30(8), 745765. https://doi.org/10.1080/09588221.2017.1347572

Logan, J. W., Lundberg, O. H., Roth, L., \& Walsh, K. R. (2017). The Effect of Individual Motivation and Cognitive Ability on Student Performance Outcomes in a Distance Education Environment. Journal of Learning in Higher Education, 13(1), 83-91.

Lu, C., Tsai, C.-C., \& Wu, D. (2015). The Role of ICT Infrastructure in Its Application to Classrooms: A Large Scale Survey for Middle and Primary Schools in China. Journal of Educational Technology \& Society, 18(2), 249- 
INTERNATIONAL JOURNAL OF ACADEMIC RESEARCH IN PROGRESSIVE EDUCATION AND

DEVELOPMENT

Vol. 10, No. 2, 2021, E-ISSN: 2226-6348 @ 2021 HRMARS

261. https://www.jstor.org/stable/jeductechsoci.18.2.249

Maher, D. (2019). Barriers to ICT use in EFL teacher education courses in Nepal: An activity theory perspective. Journal of NELTA, 24(1-2), 77-94. https://doi.org/10.3126/nelta.v24i1-2.27681

Mahmood, S. (2021). Instructional Strategies for Online Teaching in COVID-19 Pandemic. Human Behavior and Emerging Technologies, 3(1), 199203. https://doi.org/10.1002/hbe2.218

Mansilla-Villanueva, E. (2020, July). ICT policies in Latin America: Long-term inequalities and the role of globalized policy-making / First Monday. https://journals.uic.edu/ojs/index.php/fm/article/view/10865

McCombes, S. (2019, May 1). Correlational Research / Definition, Methods and Examples. Scribbr. https://www.scribbr.com/methodology/correlational-research/

McMurtry, K. (2016). Effective Teaching Practices in Online Higher Education. CCE Theses and Dissertations. https://nsuworks.nova.edu/gscis_etd/372

Mehta, R. (2018). Multiple Perspectives on Strengthening the Ability of Teacher Education Programs to Prepare Teacher Candidates to Integrate Technology-Learning \& Technology Library (LearnTechLib). https://www.learntechlib.org/p/182809/

Mercader, C., \& Gairín, J. (2020). University teachers' perception of barriers to the use of digital technologies: The importance of the academic discipline. International Journal of Educational Technology in Higher Education, 17(1), 4. https://doi.org/10.1186/s41239020-0182-x

M'kulama, A. C. M., Mwiinga, T. M., Chisunka-Mwila, C. P., \& Daka, K. L. (2020). Use of Digital Reference Services in Selected Academic Libraries in Zambia. http://dspace.unza.zm/handle/123456789/6404

Meyer, I. A., \& Gent, P. R. (2016). The Status of ICT in Education in South Africa and The Way Forward. NECT.Org.Za, 2016., 54.

Mills, I. (2017). Competing Interests: Understanding the Implications of the Emergent International ICT Governance Network (SSRN Scholarly Paper ID 2944408). Social Science Research Network. https://papers.ssrn.com/abstract=2944408

Mlotshwa, H. F. (2019). Exploring ICT pedagogic integration of economics teachers in two Johannesburg schools [Thesis]. http://wiredspace.wits.ac.za/handle/10539/28000

Monaco, A., Maggi, S., De Cola, P., Hassan, T. A., Palmer, K., \& Donde, S. (2019). Information and communication technology for increasing healthy ageing in people with noncommunicable diseases: Identifying challenges and further areas for development. Aging Clinical and Experimental Research, 31(11), 1689-1693. https://doi.org/10.1007/s40520019-01258-8

Moussalem, H., Hussein, B., Merhi, Z., \& Haj-Ali, A. (2018). An LCT-Based Higher Education System: Involving Students in the Quality Assurance Process. 2018 International Conference on Computer and Applications (ICCA), 265269. https://doi.org/10.1109/COMAPP.2018.8460328

Mtebe, J. (2020). Applying UNESCO ICT Competency Framework to Evaluate Teachers' ICT Competence Levels in Tanzania: Education Book Chapter / IGI Global. https://www.igi- 
INTERNATIONAL JOURNAL OF ACADEMIC RESEARCH IN PROGRESSIVE EDUCATION AND

DEVELOPMENT

Vol. 10, No. 2, 2021, E-ISSN: 2226-6348 @ 2021 HRMARS

global.com/chapter/applying-unesco-ict-competency-framework-to-evaluate-teachersict-competence-levels-in-tanzania/231167

Muenks, K., \& Miele, D. (2017, February). Students' Thinking About Effort and Ability: The Role of Developmental, Contextual, and Individual Difference Factors-Katherine Muenks, David B. Miele, 2017. https://journals.sagepub.com/doi/abs/10.3102/0034654316689328

Njenga, J. K. (2018). Sociocultural paradoxes and issues in e-learning use in higher education Africa. Globalisation, Societies and Education, 16(1), 120-

133. https://doi.org/10.1080/14767724.2017.1390664

Ogunmakin, D. R. (2018). ICT- Based Instructional Practices: An Assessment of inService Teachers in Ondo State. 6, 15.

Paul, J., \& Jefferson, F. (2019). A Comparative Analysis of Student Performance in an Online vs. Face-to-Face Environmental Science Course From 2009 to 2016. Frontiers in Computer Science, 1. https://doi.org/10.3389/fcomp.2019.00007

Pellas, N., Kazanidis, I., Konstantinou, N., \& Georgiou, G. (2017). Exploring the educational potential of three-dimensional multi-user virtual worlds for STEM education: A mixedmethod systematic literature review. Education and Information Technologies, 22(5), 2235-2279. https://doi.org/10.1007/s10639-016-9537-2

Picciano, A. G. (2017). Theories and Frameworks for Online Education: Seeking an Integrated Model. Online Learning, 21(3). https://doi.org/10.24059/olj.v21i3.1225

Rabin, E., Henderikx, M., Yoram, M. K., \& Kalz, M. (2020). What are the barriers to learners' satisfaction in MOOCs and what predicts them? The role of age, intention, self-regulation, self-efficacy and motivation. Australasian Journal of Educational Technology, 36(3), 119131. https://doi.org/10.14742/ajet.5919

Rahimi, B., Nadri, H., Afshar, L. H., \& Timpka, T. (2018). A Systematic Review of the Technology Acceptance Model in Health Informatics. Applied Clinical Informatics, 9(3), 604-634. https://doi.org/10.1055/s-0038-1668091

Rajabalee, B. Y., Santally, M. I., \& Rennie, F. (2020). A study of the relationship between students' engagement and their academic performances in an eLearning environment. E-Learning and Digital Media, 17(1), 1-20. https://doi.org/10.1177/2042753019882567

Rajalingam, P., Rotgans, J. I., Zary, N., Ferenczi, M. A., Gagnon, P., \& Low-Beer, N. (2018). Implementation of team-based learning on a large scale: Three factors to keep in mind*. Medical Teacher, 40(6), 582-588.

https://doi.org/10.1080/0142159X.2018.1451630

Ramadan, A., \& Chen, X. (2018). Teachers' Perceptions on ICT integration in TVET Classes: A Case Study in Khartoum State-Sudan. People: International Journal of Social Sciences, 4(2), 639-654. https://grdspublishing.org/index.php/people/article/view/1461

Ramirez, I., Infante, A., Pantrigo, J., Montemayor, A., Moreno, J. L., Alonso, V., Anguita, G., \& Palombarani, L. (2018, March). Convolutional neural networks for computer vision-based detection and recognition of dumpsters /

SpringerLink. https://link.springer.com/article/10.1007/s00521-018-3390-8

Rossi, M. D. (2019). Towards an ICT-TPCK based design: Hybrid Solution for the development of soft skills in Higher Education. Education Sciences \& Society - Open Access, 9(2), Article 2. http://ojs.francoangeli.it/_ojs/index.php/ess/article/view/6893 
INTERNATIONAL JOURNAL OF ACADEMIC RESEARCH IN PROGRESSIVE EDUCATION AND

DEVELOPMENT

Vol. 10, No. 2, 2021, E-ISSN: $2226-6348$ @ 2021 HRMARS

Rubio-Torres. (2019) The Potential of English Language Teaching Through ICT; https://hdl.handle.net/10953.1/11626

Rusman, T., Maskun, M., \& Suroto, S. (2021, March 24). Constraints to the Application of Online Learning during the Covid-19 Pandemic. Proceedings of the 2nd International Conference on Progressive Education, ICOPE 2020, 16-17 October 2020, Universitas Lampung, Bandar Lampung, Indonesia. https://eudl.eu/doi/10.4108/eai.16-10-2020.2305258

Saal, P. E., Graham, M. A., \& Ryneveld, L. van. (2020). The Relationship between Integrating Educational Technology in Mathematics Education and the Mathematics Achievement of German Students. Eurasia Journal of Mathematics, Science and Technology Education, 16(12), em1905. https://doi.org/10.29333/ejmste/8939

Saubern, R., Urbach, D., Koehler, M., \& Phillips, M. (2020). Describing increasing proficiency in teachers' knowledge of the effective use of digital technology. Computers \& Education, 147, 103784. https://doi.org/10.1016/j.compedu.2019.103784

Schindler, L. A., Burkholder, G. J., Morad, O. A., \& Marsh, C. (2017). Computerbased technology and student engagement: A critical review of the literature. International Journal of Educational Technology in Higher Education, 14(1), 25. https://doi.org/10.1186/s41239-017-0063-0

Semerci, Ç., Batdi, V., \& Aslan, A. (2018). A meta-analytic and thematic study concerning the effect of inquiry based instruction on learners' achievement. Educational Policy Analysis and Strategic Research, 13, 518. https://doi.org/10.29329/epasr.2018.143.3

SWAN Research | SWAN. (2017). https://www.swan-forum.com/swan-research/

Teresa, S. F., Shah, M., Graziano, K. J., Schmidt-Crawford, D. A., Slykhuis, D. A., Mehta, R., Lyublinskaya, I., \& Sprague, D. (2018). Multiple Perspectives on Strengthening the Ability of Teacher Education Programs to Prepare Teacher Candidates to Integrate Technology. 2041-2046. https://www.learntechlib.org/primary/p/182809/

Tomaro, Q. P. (2018). ICT integration in the educational system of Philippines / Tomaro / Journal of Governance and Public

Policy. https://journal.umy.ac.id/index.php/GPP/article/view/4965

Tondeur, J., van Braak, J., Ertmer, P. A., \& Ottenbreit-Leftwich, A. (2017). Understanding the relationship between teachers' pedagogical beliefs and technology use in education: A systematic review of qualitative evidence. Educational Technology Research and Development, 65(3), 555-575. https://doi.org/10.1007/s11423-016-9481-2

Tondeur, J., Forkosh-Baruch, A., Prestridge, S., Albion, P., \& Edirisinghe, S. (2016). Responding to Challenges in Teacher Professional Development for ICT Integration in Education. Journal of Educational Technology \& Society, 19(3), 110-

120. https://www.jstor.org/stable/jeductechsoci.19.3.110

Tor, S. F., Wisdom, A. G., \& Ezekiel, P. (2020, January 9). An Appraisal of the Functionality, Adequacy and Use of ICT Tools to Enhance Web-Based Learning in Benue State University, Makurdi. Centre for Advanced Research \&

Development. https://casirmediapublishing.com/2020/01/09/an-appraisal-of-thefunctionality-adequacy-and-use-of-ict-tools-to-enhance-web-based-learning-in-benuestate-university-makurdi/ 
INTERNATIONAL JOURNAL OF ACADEMIC RESEARCH IN PROGRESSIVE EDUCATION AND

DEVELOPMENT

Vol. 10, No. 2, 2021, E-ISSN: 2226-6348 @ 2021 HRMARS

Turan, Z., \& Göktaş, Y. (2018). Innovative Redesign of Teacher Education ICT Courses: How Flipped Classrooms Impact Motivation? Journal of Education and Future, 13, 133144. https://dergipark.org.tr/en/pub/jef/390937

Tripathi, A., \& Khazanchi, D. (2018). Theoretical Trends in IS/T Leadership: A Review of Published Research. MWAIS 2018 Proceedings. https://aisel.aisnet.org/mwais2018/16

Turnip, R., Nurjanah, D., \& Kusumo, D. S. (2017). Hybrid recommender system for learning material using content-based filtering and collaborative filtering with good learners' rating. 2017 IEEE Conference on E-Learning, e-Management and e-Services (IC3e), 61-66. https://doi.org/10.1109/IC3e.2017.8409239

Valentine, S., Leyva-McMurtry, A., Borgos-Rodriguez, K., \& Hammond, T. (2016). The Digital Sash: A Sketch-Based Badge System in a Social Network for Children (pp. 179189). https://doi.org/10.1007/978-3-319-31193-7_12

Ward, F. (2019). Technology and the transmission of tradition: An exploration of the virtual pedagogies in the Online Academy of Irish Music. Journal of Music, Technology and Education, 12(1), 5-23. https://doi.org/10.1386/jmte.12.1.5_1

Yamaguchi, S. (2018) Understanding factors affecting primary school teachers' use of ICT for student-centered education in Mongolia. International Journal of Education and Development using ICT, 14(1), https://www.learntechlib.org/p/183555/

Yang, J., Pan, H., Zhou, W., \& Huang, R. (2018). Evaluation of smart classroom from the perspective of infusing technology into pedagogy. Smart Learning Environments, 5(1), 20. https://doi.org/10.1186/s40561-018-0070-1

Zamir, S., \& Thomas, M. (2019). Effects of University Teachers' Perceptions, Attitude and Motivation on Their Readiness for the Integration of ICT in Classroom Teaching. Journal of Education and Educational Development, 6(2), 308326. https://eric.ed.gov/?id=EJ1235001

Zanatta, F., Sainz, M. G., \& Gillett-Swan, J. (2019). A Critical Realist Reflection on the Use of Social Media as Third Space for Rights Education in Early Childhood. International Journal of Early Childhood, 51(3), 319333. https://doi.org/10.1007/s13158-019-00249-0

Zhou, M., \& Teo, T. (2017). Exploring Student Voice in Teachers' Motivation to Use ICT in Higher Education: Qualitative Evidence from a Developing Country. International Journal of Educational Technology, 4(1), 26-33. https://eric.ed.gov/?id=EJ1167304

Zhuang, F., Luo, D., Yuan, N. J., Xie, X., \& He, Q. (2017). Representation Learning with Pair-wise Constraints for Collaborative Ranking. Proceedings of the Tenth ACM International Conference on Web Search and Data Mining, 567575. https://doi.org/10.1145/3018661.3018720 